\title{
Pengembangan modul praktikum matakuliah Pancasila dengan model project citizen untuk menanamkan nilai-nilai antikorupsi pada mahasiswa
}

\author{
Galih Puji Mulyoto a \\ a Pendidikan Guru Madrasah Ibtidaiah, Universitas Islam Negeri Maulana Malik Ibrahim, \\ Kota Malang, Indonesia
}

\begin{abstract}
ABSTRAK
Proses penanaman nilai-nilai antikorupsi dikalangan mahasiswa harus terpadu antara teori dan praktik. Faktanya, praktik lapangan terkait penanaman nilai-nilai antikorupsi pada matakuliah Pendidikan Pancasila di Perguruan Tinggi minim sekali diterapkan. Salah satu faktor kesulitan mahasiswa maupun dosen dalam melaksanakan praktik lapangan karena tidak adanya modul praktikum. Oleh karena itu penelitian ini mengembangkan modul praktikum menggunakan model project citizen pada matakuliah Pendidikan pancasila untuk menanamkan nilai-nilai antikorupsi pada mahasiswa FITK UIN Maulana Malik Ibrahim Malang. Penelitian ini dirancang dengan menggunakan model pengembangan pembelajaran Walter Dick \& Lou Carey. Kelayakan dan keefektifan pengembangan modul praktikum menggunakan project citizen pada matakuliah pancasila dapat untuk menanamkan nilai-nilai antikorupsi. Terdapat perbedaan signifikan pada menanamkan keterampilan dan sikap tentang nilai-nilai antikorupsi pada mahasiswa setelah menggunakan modul praktikum berbasis project citizen dari hasil produk pengembangan. Selain itu, modul praktikum berbasis Project Citizen Terbukti secara signifikan efektif untuk menanamkan keterampilan dan sikap tentang nilai-nilai antikorupsi pada mahasiswa.
\end{abstract}

\section{ABSTRACT}

The process of teaching anti-corruption values among students must integrate between theory and practice. Field practices related to instilling anti-corruption benefits in the Pancasila Education course in tertiary institutions are very minimal. One factor is the difficulty of students and lecturers in carrying out field practice because there is no practicum module. Therefore this study developed a practical module using the Project Citizen Model in Pancasila Education courses to instill anti-corruption values in FITK UIN students Maulana Malik Ibrahim Malang. This research designed using Walter Dick \& Lou Carey's learning development model. The feasibility and effectiveness of the development of practical modules using project citizen in Pancasila courses can instill anti-corruption values. The results showed that there were significant differences in teaching skills and attitudes about anti-corruption values in students after using the Project Citizen-based practical module from the product development results. Besides that, the Project Citizenbased practical module proved to be significantly effective in instilling skills and attitudes about anti-corruption values in students.

\section{Sejarah Artikel}

Diterima : 3 April 2020

Disetujui : 30 April 2020

Kata kunci:

Modul praktikum, model project citizen, nilai-nilai antikorupsi

\section{Keywords:}

Practicum module, project citizen model, anti-corruption values

\section{Pendahuluan}

Seluruh elemen bangsa Indonesia pada hakikatnya mempunyai kepentingan bersama yaitu memberantas korupsi. Dasarnya, korupsi di Indonesia sekarang ini merupakan kejahatan luar biasa, karena berdampak sistemis dan merugikan negara. Menurut hasil kajian Laboratorium IImu Ekonomi Universitas Gadjah Mada (UGM), menunjukkan biaya sosial korupsi yang mencapai Rp 509, 57 triliun. Namun, hal ini, menurut KPK angka tersebut bisa lebih besar lagi (Fadhil, 2019). Fakta tersebut menunjukkan bahwa upaya pemberantasan korupsi di Indonesia harus menjadi perhatian khusus seluruh komponen bangsa. 
Gerakan sosial antikorupsi merupakan kebangkitan masyarakat untuk bersama-sama mengoreksi kondisi dan menghadirkan kehidupan lebih baik. Tujuan akhirnya tidak hanya perubahan sikap dan perilaku individu di dalam masyarakat itu sendiri, melainkan juga memunculkan tatanan sosial baru yang bebas korupsi (Komisi Pemberantasan Korupsi, 2016). Dalam konteks inilah mahasiswa sebagai salah satu bagian penting dari masyarakat sangat diharapkan dapat berperan aktif.

Mahasiswa sebagai calon pemimpin masa depan diharapkan mampu menghindarkan diri dari perilaku koruptif maupun tindak korupsi. Namun faktanya, dalam kehidupan sehari-hari perilaku mahasiswa bahkan cenderung mengarah kepada tindakan koruptif. Hal ini dapat diketahui hasil penelitian yang dilakukan oleh Falah (2012) menunjukkan bahwa mahasiswa menilai perilaku korupsi yang dilakukan oleh pihak-pihak yang tidak memiliki keterlibatan dengan dirinya sebagai hal yang negatif, namun bila ada keterlibatan dengan dirinya mereka cenderung menoleransi. Wajar apabila, sangat penting penanaman nilai-nilai antikorupsi diberikan pada mahasiswa di bangku perkuliahan (Komisi Pemberantasan Korupsi, 2016).

Rencananya kementerian Pendidikan dan Kebudayaan, Kementerian Ristek-Dikti dan Kementerian Agama RI telah sepakat pada tahun 2019 Sekolah/Madrasah hingga Universitas segera terapkan kurikulum antikorupsi (Koran Sindo, 2018). Sementara itu, di lingkungan Perguruan Tinggi Agama Islam (PTAl), Kementerian Agama RI telah mengeluarkan peraturan Nomor: 341/7/Tahun 2014 Tentang Penetapan Sasaran Implementasi Model Pendidikan Integritasi Anti Korupsi Tahun Anggaran 2014. Dimana UIN Maulana Malik Ibrahim Malang sebagai sasaran implementasi.

Praktiknya, berdasarkan hasil pra-penelitian yang dilakukan di UIN Maulana Malik Ibrahim Malang penanaman nilai-nilai Antikorupsi ini masih disisipkan pada matakuliah kurikulum inti dan kurikulum institusional. Kurikulum inti meliputi mata kuliah Kewarganegaraan (civic Education) dan mata kuliah Pancasila. Dampaknya, ditemukan bahwa penanaman nilai-nilai antikorupsi kepada mahasiswa khususnya Fakultas IImu Tarbiyah dan Keguruan (FITK) UIN Maulana Malik Ibrahim Malang belum maksimal. Alasannya, karena penanaman nilai-nilai antikorupsi hanya disisipkan pada satu hingga dua pertemuan pada matakuliah Pancasila. Temuan kedua, rata-rata pengajar/Dosen mata kuliah Pancasila belum memiliki pemahaman yang cukup terkait praktikum penanaman nilai-nilai antikorupsi kepada mahasiswa. Temuan terakhir adalah minimnya jumlah buku modul/modul tentang praktikum penanaman nilai-nilai antikorupsi pada mahasiswa matakuliah Pancasila di FITK UIN Maulana Malik Ibrahim Malang. Karenanya, matakuliah Pancasila di FITK perlu mengembangkan modul terkait praktikum penanaman nilai-nilai antikorupsi kepada mahasiswa.

Pengembangan modul praktikum dalam matakuliah Pancasila yang mampu menanamkan nilai-nilai antikorupsi pada mahasiswa salah satunya menggunakan model project citizen. Model project citizen dikembangkan dari Center Civic Education (CCE) Amerika Serikat dan telah di adopsi di Indonesia ke dalam mata kuliah Pancasila di perguruan tinggi (Nurwardani et al., 2016). Strategi instruksional yang digunakan pada dasarnya bertolak dari strategi "inquiry learning, discovery learning, problem solving learning, research-oriented learning (belajar melalui penelitian, penyingkapan, pemecahan masalah)" yang dikemas dalam model "project "ala John Dewey (Nurwardani et al., 2016). Pengembangan modul praktikum dengan menggunakan Model project citizen diharapkan menjadi solusi penanaman nilai-nilai antikorupsi pada mahasiswa FITK UIN Maulana Malik Ibrahim Malang. Penerapan modul praktikum dengan menggunakan model project citizen akan membentuk mahasiswa untuk berpartisipasi aktif terhadap isu-isu korupsi di sekitar lingkungan mereka dan memiliki perilaku yang mencerminkan nilai-nilai antikorupsi. Kebaruan 
modul yang dikembangkan ini adalah berisi petunjuk yang disertai gambar-gambar, alur praktik dan daftar pertanyaan yang didesain dengan menarik, serta memudahkan mahasiswa dalam menjalankan praktik di lapangan.

Berdasarkan fakta dan permasalahan di atas, sangat penting menanamkan nilai-nilai antikorupsi pada mahasiswa dalam kehidupan sehari-hari. Oleh karena itu, peneliti mengajukan penelitian dengan fokus pada pengembangan modul praktikum menggunakan model project citizen sebagai upaya menanamkan nilai-nilai antikorupsi pada mahasiswa FITK UIN Maulana Malik Ibrahim Malang. Tujuan penelitian ini: mampu mengembangkan modul praktikum menggunakan project citizen pada matakuliah Pendidikan pancasila dapat menanamkan nilai-nilai antikorupsi pada mahasiswa FITK UIN Maulana Malik Ibrahim Malang. Kedua, mengetahui efektifitas dari pengembangan modul praktikum menggunakan project citizen pada matakuliah Pendidikan pancasila dalam menanamkan nilai-nilai antikorupsi pada mahasiswa FITK UIN Maulana Malik Ibrahim Malang.

\section{Metode}

Metode yang digunakan dalam penelitian ini adalah metode penelitian dan pengembangan. Penelitian ini bertujuan untuk menghasilkan produk tertentu dan menguji keefektifan produk berupa modul praktikum Pendidikan Pancasila berbasis project citizen untuk menanamkan nilainilai antikorupsi pada mahasiswa. Hasil produk tertentu digunakan penelitian yang bersifat analisis kebutuhan dan untuk menguji keefektifan produk tersebut supaya dapat menanamkan nilai-nilai antikorupsi pada mahasiswa, maka diperlukan penelitian untuk menguji keefektifan produk tersebut. Jadi penelitian dan pengembangan bersifat longitudinal atau bertahap.

Penelitian ini dirancang dengan menggunakan model pengembangan pembelajaran Walter Dick \& Lou Carey. Penggunaan model yang dikembangkan Walter Dick \& Lou Carey terhadap produk modul praktikum Pendidikan Pancasila berbasis Project citizen bertujuan untuk menanamkan nilai-nilai antikorupsi pada mahasiswa. Adapun langkah-langkah tersebut dapat diilustrasikan dalam gambar adaptasi Walter Dick \& Carey sebagai berikut:

1. Identifying Instructional Goal (mengidentifikasi tujuan umum pembelajaran)

2. Conducting Instructional Analysis ( melaksanakan analisis pembelajaran)

3. Identifying Entry Behaviors, Characteristics (Mengenal tingkah laku masukan dan karakteristik mahasiswa)

4. Writing Performance Objectives (merumuskan tujuan khusus pembelajaran)

5. Developing Criterion-Referenced Test (mengembangkan butir tes acuan patokan/Criterion Referenced Test)

6. Developing Instructional Strategy (mengembangkan strategi pembelajaran)

7. Developing and Selecting Instruction (menyeleksi dan mengembangkan bahan pembelajaran)

8. Designing and Conducting Formative Evaluation (merancang dan melaksanakan evaluasi formatif)

9. Revising Instruction (merevisi bahan pembelajaran)

10. Designing and Conducting Formative Summative (merancang dan melaksanakan evaluasi sumatif) (Dick, 1996).

\section{Hasil dan Pembahasan}

Landasan pembelajaran pendidikan Pancasila di perguruan tinggi sesuai dengan amanat dari Undang-Undang Nomor 12 Tahun 2012 tentang Pendidikan Tinggi, Pasal 35 Ayat 3 menyatakan bahwa kurikulum pendidikan tinggi wajib memuat mata kuliah Agama, Pancasila, Pendidikan Kewarganegaraan, dan Bahasa Indonesia untuk program sarjana dan diploma. Selain itu, 
berdasarkan Instruksi Presiden Nomor 12 Tahun 2016 tentang Gerakan Nasional Revolusi Mental, dalam melaksanakan butir kelima, bahwa untuk mewujudkan generasi bangsa Indonesia yang berkarakter tangguh, cinta tanah air, bela negara serta mampu meningkatkan jati diri bangsa, maka pendidikan Mata Kuliah Wajib Umum (MKWU) diperkuat sebagai salah satu komponen pembentuk budaya bangsa.

Berdasarkan aturan tersebut, Universitas Islam Negeri Maulana Malik Ibrahim Malang mengajarkan pendidikan pancasila sebagai Mata Kuliah kepribadian (MKK) yang wajib diajarkan dan dimasukkan ke dalam kurikulum setiap program studi di lingkungan Universitas Islam Negeri Maulana Malik Ibrahim Malang.

Mata kuliah ini memberikan pemahaman tentang konsep Pancasila sebagai dasar falsafah negara dan segala hal yang terkait dengan eksistensi dan perwujudan nilai-nilai Pancasila dalam kehidupan bermasyarakat berbangsa dan bernegara di setiap bidang pembangunan. Dalam mata kuliah ini dibahas Pengantar Mata Kuliah, Pancasila dalam Kajian, Sejarah Bangsa Indonesia, Pancasila sebagai Dasar Negara, Pancasila sebagai Ideologi negara, Simbol-simbol Pancasila, Pancasila sebagai Sistem Filsafat, Pancasila sebagai Sistem Etika, dan Pengamalan Pancasila (Analisis hakikat Pancasila).

Sistem pengajaran pendidikan pancasila yang diajarkan memadukan kurikulum yang sesuai dengan KKNI serta terintegrasi dengan nilai-nilai dalam ajaran agama Islam sehingga mampu melahirkan generasi ulu al-albab berjiwa Pancasila. Untuk mewujudkan orang-orang yang memiliki ciri-ciri pokok antara lain: beriman, berpengetahuan luas, berakhlak mulia, tekun beribadah, berjiwa sosial dan bertakwa, pengembangan pembelajaran pendidikan Pancasila mengedepankan tidak hanya pada aspek pengetahuan tetapi juga sikap dan keterampilan.

Program yang disusun dalam proses pembelajaran mengedepankan konsep dalam tridharma perguruan tinggi yaitu penelitian, pengabdian dan pengajaran. Konsep penelitian dibangun untuk mengajak mahasiswa melakukan kajian terhadap tantangan serta dinamika Pancasila dalam masyarakat. Penelitian ini merupakan mini research untuk mengajak mahasiswa berfikir kritis terkait permasalahan di masyarakat/lingkungan sekitar mereka terkait pancasila. Hasilnya adalah luaran berupa artikel yang dimuat di jurnal ilmiah.

Pengabdian diajarkan setelah tengah semester dengan tujuan mahasiswa mampu mengamalkan nilai-nilai pancasila dalam kehidupan sehari-hari. Pembelajaran disusun dengan membuat rencana memberikan santunan kepada anak-anak yatim di panti asuhan. Proses pembelajaran mampu mengajarkan mahasiswa tentang nilai-nilai kehidupan serta mampu mempraktikkan pengamalan pancasila secara langsung. Hasil akhir pengabdian ini adalah film dokumenter kegiatan pengabdian yang diunggah melalui YouTube. Selain itu, konsep pembelajaran pendidikan pancasila telah menggunakan pembelajaran berbasis teknologi dengan model blended learning atau hybrid learning sebagai persiapan menyongsong era revolusi industri 4.0 bidang pendidikan. Hal ini sebagai menjawab tuntutan zaman dalam Perkembangan pendidikan abad 21 yang telah mengembangkan 4c, HOTS, literasi serta PPK.

Proses penyusunan pengembangan modul praktikum mata kuliah Pendidikan Pancasila dengan model project citizen sebagai upaya menanamkan nilai-nilai anti korupsi pada mahasiswa. Langkah ini mengacu kepada pada latar belakang masalah yang dikemukakan bahwa terbatasnya modul praktik untuk matakuliah Pendidikan Pancasila.

Pengembangan modul praktikum mata kuliah Pendidikan Pancasila dengan model project citizen sebagai upaya menanamkan nilai-nilai anti korupsi pada mahasiswa menggunakan model Dick and Carrey terdapat 10 tahapan desain pengembangan, akan tetapi dalam pengembangan 
ini hanya dilakukan 9 tahap saja, karena pengembangan hanya pada sebatas uji prototipe produk. Implementasi model desain sistem pembelajaran ini memerlukan proses yang sistematis yang menyeluruh. Hal ini diperlukan untuk dapat menciptakan desain sistem pembelajaran yang mampu digunakan secara optimal dalam mengatasi masalah-masalah pembelajaran.

Proses penyusunan modul praktikum berbasis project citizen pada mata kuliah Pendidikan Pancasila ini adalah sebagai pendamping mahasiswa dalam menanamkan nilai-nilai antikorupsi. Untuk itu, pengembangan modul praktikum matakuliah Pendidikan Pancasila dengan model Project citizen sebagai upaya menanamkan nilai-nilai anti korupsi pada mahasiswa dilakukan validasi oleh ahli isi, dan ahli desain pembelajaran, sebelum di uji cobakan di lapangan.

\section{Uji Produk (Ahli Isi)}

\section{Penyajian Data}

Berdasarkan hasil penilaian ahli desain modul (lampiran gambar 1) terhadap modul praktikum mata kuliah Pendidikan Pancasila dengan model Project citizen, maka dapat dihitung persentase tingkat pencapaian modul praktikum mata kuliah Pendidikan Pancasila dengan model Project citizen (lampiran rumus persentase 1). Karena bobot setiap pilihan adalah 1, maka persentase $90 \%$. Setelah dikonversi dengan table konversi skala 5, persentase tingkat pencapaian 90\% berada pada kualifikasi sangat baik, sehingga modul praktikum mata kuliah Pendidikan Pancasila dengan model project citizen tidak perlu direvisi.

Adapun data kualitatif yang dihimpun dari masukan, saran dan komentar ahli desain modul dalam pertanyaan terbuka yang berkenaan dengan modul praktikum mata kuliah Pendidikan Pancasila dengan model project citizen. Hasil saran dipaparkan pada tabel 1 ikhtisar data penilaian dan review ahli desain pembelajaran (lampiran tabel 1 Ikhtisar Data Penilaian dan Review Ahli Desain Pembelajaran).

Semua data hasil review, penilaian dan diskusi ahli desain modul. Hasilnya dijadikan landasan untuk merevisi penyempurnaan desain modul praktikum mata kuliah Pendidikan Pancasila dengan model project citizen sebelum uji coba kepada mahasiswa.

\section{Revisi Produk Pengembangan}

Berdasarkan hasil penilaian atau tanggapan ahli desain modul yang terdapat pada angket tidak perlu mendapat revisi. Akan tetapi masukan, saran, dan komentar yang disampaikan oleh ahli desain pembelajaran dalam angket pertanyaan terbuka, berusaha diwujudkan dengan sebaikbaiknya agar pengembangan modul praktikum mata kuliah Pendidikan Pancasila dengan model project citizen semakin baik. Revisi modul praktikum mata kuliah Pendidikan Pancasila dengan model project citizen disajikan sebagai berikut:

1) Cover belakang buku yang semulanya bertuliskan warna kuning diganti dengan putih

2) Warna background yang semulanya hijau tua diganti dengan putih

3) Pada halaman tadinya ditulis tanda gambar, diganti dengan menggunakan gambar disesuaikan dengan konten

4) Penggunaan warna yang terlalu banyak sudah pengembang kurangi yaitu dengan menggunakan warna dominan putih dengan gambar instruksi praktikum

\section{Tingkat Efektifitas, Efisien, dan Kemenarikan Modul}

Pada langkah ini, digunakan untuk mengetahui tingkat efektifitas, efisien, dan kemenarikan modul praktikum berbasis Project citizen. Berikut ini akan dipaparkan hasil dari uji coba kelompok kecil, uji coba lapangan, dan data pre-test dan post-test. 


\section{Uji Coba Lapangan}

Produk pengembangan yang diserahkan kepada uji coba lapangan yang diwakili oleh satu kelas yakni mahasiswa kelas Bk Jurusan Tadris Bahasa Inggris, Fakultas Ilmu Tarbiyah dan Keguruan, UIN Maulana Malik Ibrahim Malang yang berjumlah 39 mahasiswa. Adapun data kuantitatif dari hasil penilaian uji coba lapangan sebanyak 39 orang adalah sebagaimana dipaparkan dalam gambar 2 hasil Uji Produk di Lapangan (lampiran gambar 2 hasil Uji Produk di Lapangan).

Berdasarkan hasil uji coba lapangan terhadap modul praktikum berbasis Project citizen matakuliah Pendidikan Pancasila sebagaimana dicantumkan dalam gambar 2, maka dapat dihitung persentase tingkat pencapaian modul praktikum berbasis Project citizen dapat dilihat pada lampiran rumus persentase 2.

Karena bobot setiap pilihan adalah 1, maka persentase $800 \%$. Setelah dikonversi dengan table konversi skala 5, persentase tingkat pencapaian $80 \%$ berada pada kualifikasi baik, sehingga modul praktikum berbasis Project citizen tidak perlu di revisi. Berdasarkan gambar 2 tentang penilaian uji coba lapangan terhadap produk pengembangan modul praktikum berbasis Project citizen matakuliah Pendidikan Pancasila, dapat dinilai dengan persentase $80 \%$ dari kriteria yang telah ditetapkan.

\section{Revisi Produk Pengembangan}

Berdasarkan hasil penilaian uji coba lapangan dengan tingkat pencapaian rata-rata $80 \%$, maka pada dasarnya modul praktikum berbasis Project citizen matakuliah Pendidikan Pancasila produk pengembangan tidak perlu mendapat revisi. Akan tetapi masukan, saran dan komentar yang telah disampaikan oleh responden uji coba lapangan, berusaha diwujudkan dengan sebaikbaiknya sehingga akan lebih menyempurnakan modul praktikum berbasis Project citizen.

Adapun revisi produk pengembangan berupa modul praktikum berbasis Project citizen matakuliah Pendidikan Pancasila, disajikan dengan mempertimbangkan saran responden yaitu dengan memberikan contoh-contoh dalam menanamkan nilai-nilai antikorupsi dalam kehidupan sehari-hari sebagai mahasiswa.

\section{Penyajian Data Pre-Test dan Post-Test}

Tabel nilai pre-test dan post-test yang didapat dari mahasiswa kelas Bk Jurusan Tadris Bahasa Inggris, Fakultas IImu Tarbiyah dan Keguruan, UIN Maulana Malik Ibrahim Malang sejumlah 39 mahasiswa. Data diambil menggunakan penilaian sikap dan keterampilan untuk mengetahui sikap dan keterampilan awal mahasiswa tentang nilai-nilai antikorupsi. Pada saat uji coba lapangan pretest didapatkan data tabel 2 hasil uji coba lapangan pada pre-test.

Pada tabel 2 hasil pretest menunjukkan bahwa mahasiswa yang kurang dari KKM adalah sebanyak 22 Mahasiswa, dan Mahasiswa yang mencapai KKM sebanyak 17 Mahasiswa dengan. Data tersebut menunjukkan keterampilan dan sikap awal mahasiswa tentang nilai-nilai antikorupsi masih banyak dibawah kriteria ketuntasan minimal atau sebanyak 56\%. Sementara itu, 44\% tuntas memenuhi kriteria ketuntasan minimal yang diharapkan. Kesimpulan awal yang didapatkan dari data diatas adalah kemampuan awal mahasiswa baik sikap dan keterampilan tentang nilai-nilai antikorupsi masih rendah.

Pada tabel 3 hasil post-test menunjukkan bahwa mahasiswa yang kurang dari KKM 6 mahasiswa atau $15 \%$, dan mahasiswa yang mencapai KKM sebanyak siswa dengan mencapai prosentase 33 mahasiswa atau 85\% mahasiswa yang telah memenuhi kriteria, ketuntasan. Kesimpulannya adalah pembelajaran menggunakan modul praktikum berbasis Project citizen pada 
matakuliah Pancasila mampu menanamkan nilai-nilai antikorupsi kepada mahasiswa. Nilai-nilai ini tercermin dalam sikap dan keterampilan yasil produk praktikum yang dikembangkan berdasarkan modul.

Tabel 2

Hasil Uji Coba Lapangan pada Pre-Test

\begin{tabular}{cccc}
\hline Kriteria & $\mathrm{n}$ & $\mathrm{P}(\%)$ & Keterangan \\
\hline $3,66<$ & 22 & 56 & Tidak tuntas \\
$3,66>$ & 17 & 44 & Tuntas \\
\hline
\end{tabular}

Sumber: Data Hasil Penelitian, 2019

Tabel 3

Hasil Uji Coba Lapangan pada Post-Test

\begin{tabular}{cccc}
\hline Kriteria & $\mathrm{N}$ & $\mathrm{P}(\%)$ & Keterangan \\
\hline $3,33<$ & 6 & 15 & Tidak Tuntas \\
$3,33>$ & 33 & 85 & Tuntas
\end{tabular}

Sumber: Data Hasil Penelitian, 2019

Hal ini menunjukkan keefektifan dari pengembangan modul praktikum berbasis project citizen terhadap penanaman nilai-nilai antikorupsi pada mahasiswa pada matakuliah Pendidikan Pancasila. Hasil post test pada tabel 3 sudah sangat membuktikan pentingnya pengembangan modul praktikum berbasis project citizen ini. Oleh karena itu, pengembangan modul praktikum berbasis project citizen mampu menumbuhkan sikap dan keterampilan dalam menanamkan nilainilai karakter pada mahasiswa.

Data nilai pre-test dan pots test tersebut selanjutnya melalui uji t dua sampel berpasangan (paired sample t-test) dengan bantuan computer SPSS 16 (Lihat tabel 2 pada lampiran). Data ini untuk mengungkap hasil perbedaan penggunaan modul praktikum project citizen mampu menumbuhkan sikap dan keterampilan dalam menanamkan nilai-nilai karakter pada mahasiswa. Pada output diperlihatkan deskriptif dari kedua sampel yang diteliti yakni nilai pre test dan post test. Nilai pre-test diperoleh hasil rata-rata 64,97. Sedangkan untuk nilai post-test diperoleh nilai rata-rata 67,20. Jumlah responden mahasiswa yang digunakan sebanyak 39 mahasiswa. Untuk nilai std deviation pre-test sebesar 4,60256 dan post test sebesar 2,82078. Karena nilai rata-rata hasil belajar sikap pada pre test 64,97 < post-test 67,20, maka artinya secara deskriptif ada perbedaan rata-rata hasil belajar antara pre-test dan post-test. Cara membuktikan apakah benarbenar ada perbedaaan maka perlu meafsirkan hasil uji paired sample t test yang terdapat pada table output 'Paired Samples Tset". Output di atas menunjukkan sebesar 0,633 dengan nilai signifikansi sebesar 0,000. Hal ini dikarena nilai sig 0,000 <0,005, maka dikatakan bahwasannya benar-benar ada perbedaan setelah mendapatkan perlakuan dari peneliti. Perbedaan ini menunjukkan bahwa penggunaan modul praktikum berbasis project citizen mampu menanamkan sikap tentang nilai-nilai antikorupsi pada mahasiswa.

Selanjutnya, gambaran perbedaan uji t pada keterampilan mahasiswa sebelum dan sesudah menggunakan modul praktikum berbasis project citizen mampu menanamkan sikap tentang nilainilai antikorupsi pada mahasiswa. Nilai pre-test diperoleh hasil rata-rata 15.5. Sedangkan untuk nilai post test diperoleh nilai rata-rata 17.2. Jumlah responden mahasiswa yang digunakan sebanyak 39 mahasiswa. Untuk nilai std deviation pre-test sebesar 1.55337 dan post test sebesar 0.92280. Karena nilai rata-rata hasil belajar keterampilan pada pre test $15.5<$ post test 17.2 , maka artinya secara deskriptif ada perbedaan rata-rata hasil belajar terkait penanaman keterampilan nilai-nilai anti korupsi antara pre test dan post test. Cara membuktikan apakah benar-benar ada perbedaaan maka perlu meafsirkan hasil uji paired sample t test yang terdapat pada table output 
'Paired Samples Tset". (lihat tabel 2 pada lampiran). Output tersebut menunjukkan sebesar 0,501 dengan nilai signifikansi sebesar 0,001. Hal ini dikarena nilai sig 0,000 $<0,005$, maka dikatakan bahwasannya benar-benar ada perbedaan setelah mendapatkan perlakuan dari peneliti. Perbedaan ini menunjukkan bahwa penggunaan modul praktikum berbasis project citizen mampu menanamkan keterampilan tentang nilai-nilai antikorupsi pada mahasiswa.

Dalam mengambil keputusan, dapat dilihat dari sig (2 tailed), apabila sig $<0,05$ maka Ho ditolak dan Ha diterima. Hal ini berarti bahwa hasil belajar sesudah menggunakan modul praktikum berbasis project citizen mampu menanamkan keterampilan tentang nilai-nilai antikorupsi pada mahasiswa lebih baik dari pada sebelumnya. Hal ini bisa dilihat dari data sig 0,00 yang diperoleh dari hasil uji t-tes. Data menunjukkan bahwa ada perbedaan yang signifikan antara penilaian keterampilan dan sikap sesudah menggunakan modul praktikum berbasis Project citizen dibandingkan dengan sebelum menggunakan produk pengembangan.

Mengacu pada ketentuan dalam mengambil keputusan dengan penghitungan manual, maka dari data yang telah diperoleh dapat diidentifikasi bahwa skala datanya adalah interval karena ada tingkatan, distrbusi populasinya normal, pengolahan datanya menggunakan Dependent sample ttest. Kriteria ujinya adalah uji-t pada dependent sample test. Adapun rumusan $\mathrm{Ha}$ nya adalah ada perbedaan yang signifikan pada upaya dalam menanamkan keterampilan dan sikap tentang nilainilai antikorupsi pada mahasiswa setelah menggunakan modul praktikum berbasis Project citizen dari produk hasil pengembangan. Kriteria Uji t :

- Jika nilai thitung lebih besar dari pada tabel, maka signifikan, artinya: Ho ditolak, Ha diterima

- Jika nilai thitung lebih kecil dari pada ttabel, maka non signifikan, artinya: Ho diterima, Ha ditolak.

Hipotesisnya adalah diterima karena t hitung > dari t tabel, sehingga kesimpulannya, ada perbedaan yang signifikan pada menanamkan keterampilan dan sikap tentang nilai-nilai antikorupsi pada mahasiswa setelah menggunakan modul praktikum berbasis Project citizen dari hasil produk pengembangan dan dapat dikatakan bahwa modul praktikum berbasis Project citizen terbukti secara signifikan efektif untuk menanamkan keterampilan dan sikap tentang nilai-nilai antikorupsi pada mahasiswa.

Penggunaan modul praktikum berbasis project citizen pada matakuliah Pendidikan Pancasila terbukti secara signifikan efektif untuk menanamkan keterampilan dan sikap tentang nilai-nilai antikorupsi pada mahasiswa. Modul praktikum ini memiliki langkah-langkah pembelajaran sebagai berikut: (1) melakukan identifikasi masalah, (2) memilih masalah sebagai bahan kajian, (3) mengumpulkan masalah yang akan dikaji, (4) mengembangkan portofolio, (5) menyajikan portofolio (6) refleksi pengalaman belajar. Dalam hal ini, langkah-langkah dalam model project citizen dipadukan dengan pendekatan saintifik yang memiliki 5 langkah pembelajaran (1) mengamati, (2) menanya, (3) mengumpulkan informasi, (3) mengasosiasikan informasi, dan (5) mengomunikasikan memiliki tujuan yang sama, sehingga menanamkan keterampilan dan sikap tentang nilai-nilai antikorupsi pada mahasiswa.

Berdasarkan uraian di atas, modul praktikum berbasis project citizen pada mata kuliah Pendidikan Pancasila menguatkan penelitian sebelumnya yang dilakukan di Taiwan, hasil post-test, menunjukkan bahwa siswa yang berpartisipasi dalam project citizen signifikan mengungguli siswa di kelompok pembanding (Liou, 2004). Dalam hal ini, kelompok eksperimen memiliki kelebihan dalam keterampilan masyarakat, kepentingan politik dan komitmen terhadap hak-hak dan tanggung jawab warga negara. Faktor signifikan terkait dengan efek project citizen pada keterampilan dan disposisi siswa SMA Taiwan termasuk iklim kelas dan paparan berita berbagai sumber. Analisis kualitatif dari wawancara guru mengungkapkan bahwa semua peserta merespons 
positif terhadap project citizen dan menunjukkan minat dalam mengimplementasikannya dalam kelas.

Penelitian lain yang mendukung adalah penelitian di berbagai negara oleh (Craddock, Alden. Fischer, John. \& Subreenduth, 2007) bahwa Project citizen memberikan dampak/pengaruh bagi pengetahuan, sikap dan keterampilan kewarganegaraan siswa, karena Project citizen memiliki rancangan yang bersifat generik dan mudah diadaptasi dalam praktik. Project citizen memiliki dampak pada siswa dalam penguasaan pengetahuan, sikap dan keterampilan. Namun, dampak cakupan tingkat ini sangat bervariasi antara situs berbeda. Project citizen di desain dan jadi mudah disesuaikan dalam praktek (Craddock, Alden. Fischer, John. \& Subreenduth, 2007).

Selanjutnya, penelitian (Vontz et al., 2000) mengevaluasi efek dari Project citizen pada pengembangan kompetensi kewarganegaraan siswa remaja di Indiana, Latvia, dan Lithuania. Hasil yang sama dutunjukkan pengaruh project citizen dalam membangun keterampilan dan sikap warganegara menjadi cerdas dan baik. Penelitian selanjutnya, yang dilakukan oleh Tolo (1998), selama tahun 1996-1997 menemukan bahwa mayoritas siswa dan guru percaya bahwa Project citizen mampu mengembangkan penguasaaan pengetahuan warga negara, keterampilan intelektual dan partisipatif, serta watak warga negara (Tolo, 1998). Temuan kunci dari survei Tolo adalah pertama siswa yang menggunakan project citizen percaya bahwa mereka dapat dan membuat perbedaan dalam komunitas mereka, daripada yang tidak menggunakan Project citizen. Kedua siswa dan guru percaya bahwa project citizen membantu siswa mengembangkan pemahaman yang lebih besar tentang kebijakan publik, membantu siswa belajar tentang pemerintah bekerja, mengembangkan komitmen siswa untuk kewarganegaraan aktif dan pemerintahan, melibatkan siswa dalam komunitas mereka, dan membantu siswa belajar tentang masalah masyarakat tertentu. Selanjutnya siswa dan guru percaya dengan mengajarkan project citizen, siswa mampu berkomunikasi dan memiliki keterampilan penelitian; dan Siswa menikmati project citizen.

Berbagai penelitian di atas menunjukkan bahwa modul praktikum berbasis project citizen sebagai wahana melatih mahasiswa dalam menyiapkan diri sebagai warga negara yang berpatisipasi aktif dalam masyarakat dimasa mendatang. Hal ini dikarenakan dalam pembelajaran yang menggunakan project citizen, mahasiswa dihadapkan dalam masalah nyata dalam kehidupan sehari-hari. Mahasiswa secara aktif dalam memecahkan masalah disekitar mereka dan pemerintah serta masyarakat tempat mereka berinteraksi. Modul ini adalah sebagai instruktur dan fasilitator praktikum matakuliah Pendidikan Pancasila yang memberi mahasiswa tentang sumber-sumber informasi yang baru, membantu mengadakan kontak-kontak dan membekali mahasiswa pada waktu mengadakan praktikum di lapangan

Modul praktikum berbasis project citizen membantu mahasiswa dalam belajar dalam praktik menjadi warganegara memantau dan mempengaruhi kebijakan publik lebih khusus pada menumbuhkan nilai-nilai anti korupsi, serta mengembangkan keterampilan yang dibutuhkan untuk kewarganegaraan yang bertanggung jawab dan efektif, dan menjadi percaya diri mahasiswa. Selain itu mahasiswa bukan hanya untuk memahami konsep dan prinsip keilmuan, tetapi juga mengembangkan kemampuannya untuk bekerja secara kooperatif melalui kegiatan belajar praktik empirik. modul praktikum berbasis project citizen memberikan mahasiswa kesempatan untuk praktik berpartisipasi dalam pemerintahan dan masyarakat saat berlatih berpikir kritis, dialog, debat, negosiasi, kerjasama, kesopanan, toleransi, pengambilan keputusan, dan tindakan warga negara untuk kebaikan bersama. Oleh karena itu, pembelajaran akan semakin menantang, mengaktifkan dan lebih bermakna.

Keaktifan dalam pembelajaran menggunakan modul praktikum berbasis project citizen sesuai dengan tuntutan perkembangan zaman yang mengedepakan pencegahaan korupsi sejak 
dini pada jenjang Perguruan tunggu. Keterpaduan modul praktikum berbasis Project citizen mampu menanamkan sikap dan keterampilan secara utuh nilai-nilai dari anti korupsi.

Berdasarkan uraian sebelumnya dapat disimpulkan bahwa penggunaan modul praktikum berbasis project citizen pada matakuliah Pendidikan Pancasila layak dan efektif dalam menanamkan nilai-nilai antikorupsi pada mahasiswa. Selain itu, terdapat perbedaan yang positif dan signifikan dalam menanamkan nilai-nilai antikorupsi pada mahasiswa. Oleh karena itu, pengembangan matakuliah Pendidikan Pancasila perlu menerapkan praktikum kepada mahasiswa agar pembelajaran tentang menanamkan nilai-nilai antikorupsi lebih sesuai dengan tujuan pembelajaran.

\section{Simpulan}

Modul praktikum menggunakan project citizen pada matakuliah Pendidikan pancasila dapat menanamkan nilai-nilai antikorupsi pada mahasiswa FITK UIN Maulana Malik Ibrahim Malang. Kelayakan didapatkan melalui beberapa tahapan, meliputi validasi ahli Isi, Validasi ahli. Pada tahap balidasi ahli Isi modul komponen kelayakan terdapat beberapa komponen. Hasilnya menunjukkan kelayakan isi modul praktikum berbasis project citizen layak untuk dikembangkan. Selanjutnya, uji kelayakan dari Ahli Modul. Kelayakan modul praktikum berbasis project citizen berdasarkan hasil validasi ahli modul layak untuk dikembangkan menjadi media dalam pembelajaran praktikum matakuliah Pancasila. Keefektifan pengembangan modul praktikum menggunakan project citizen pada matakuliah pancasila dalam menanamkan nilai-nilai antikorupsi pada mahasiswa FITK UIN Maulana Malik Ibrahim Malang. Berdasarkan hasil uji coba produk maka dapat dikatakan bahwasannya benar-benar ada perbedaan setelah mendapatkan perlakuan dari peneliti. Perbedaan ini menunjukkan bahwa penggunaan modul praktikum berbasis project citizen mampu menanamkan keterampilan tentang nilai-nilai antikorupsi pada mahasiswa. Kesimpulannya, ada perbedaan yang signifikan pada menanamkan keterampilan dan sikap tentang nilai-nilai antikorupsi pada mahasiswa setelah menggunakan modul praktikum berbasis project citizen dari hasil produk pengembangan dan dapat dikatakan bahwa modul praktikum berbasis project citizen terbukti secara signifikan efektif untuk menanamkan keterampilan dan sikap tentang nilai-nilai antikorupsi pada mahasiswa.

\section{Ucapan Terima Kasih}

Ucapan terima kasih kepada Lembaga Penelitian \& Pengabdian Masyarakat (LP2M), Universitas Islam Negeri Maulana Malik Ibrahim Malang, yang masuk dalam Penelitian Kompetitif Pengembangan IImu (PKPI). Selanjutnya terima kasih kepada Kementerian Agama RI yang telah memberikan dana penelitian ini.

\section{Referensi}

Center for Civic Education. (2006). We the people... project citizen. Calabasas, CA: Center for Civic Education.

Craddock, Alden. Fischer, John. \& Subreenduth, S. (2007). Research report: international democratic education institute teaching for democracy (assessing project citizen in Poland, South Africa, Ukraine and the United States).

Dick, W. (1996). The systematic design of instruction. HarperCollins College Publishers.

Fadhil, H. (2019). Kerugian korupsi disebut capai Rp 509 t, KPK nilai lebih besar lagi. https://news.detik.com/berita/d-4459091/kerugian-korupsi-disebut-capai-rp-509-t-kpknilai-lebih-besar-lagi 
Falah, F. (2012). Perilaku korup di mata mahasiswa. In Seminar Nasional Psikologi Universitas Muhammadiyah Surakarta (Ed.), Prosiding Seminar Nasional Psikologi Islami (hal. 151-158). Fak Psikologi Universitas Muhammadiyah Surakarta.

Komisi Pemberantasan Korupsi. (2016). Panduan pelaksanaan program pencegahan korupsi berbasis keluarga (S. Angraeni (ed.); pertama). Komisi pemberantasan Korupsi.

Koran Sindo. (2018). Madrasah hingga universitas segera terapkan kurikulum antikorupsi. https://news.okezone.com/read/2018/12/10/65/1989139/madrasah-hingga-universitassegera-terapkan-kurikulum-antikorupsi

Liou, S.-M. (2004). The effect of we the people... Project citizen on the civic skills and dispositions of Taiwanese senior high school students. 師大學報: 教育類 (Journal of Taiwan Normal University. Education ), 49(1), 63-89.

Nurwardani, P., Saksama, H. Y., Winataputra, U. S., Budimansyah, D., Sapriya, Winarno, Mulyono, E., Prawatyani, S. J., Anwar, A. A., Evawany, Priyautama, F., \& Festan, A. (2016). Pendidikan Pancasila untuk perguruan tinggi. Ditjen Belmawa.

Tolo, K. W. (1998). An assessment of we the people...project citizen: promoting citizenship in classrooms and communities. Lyndon B. School of Public Affairs, The University of Texas Austin.

Vontz, T. S., Metcalf, K. K., \& Patrick, J. J. (2000). "Project Citizen" and the civic development of adolescent students in Indiana, Latvia, and Lithuania. ERIC Clearinghouse for Social Studies. 
Galih Puji Mulyoto. Pengembangan modul praktikum mata kuliah Pancasila menggunakan model project citizen sebagai upaya menanamkan nilai-nilai antikorupsi pada mahasiswa

\section{Lampiran}

Gambar 1

Grafik Hasil Penilaian Ahli Desain Modul

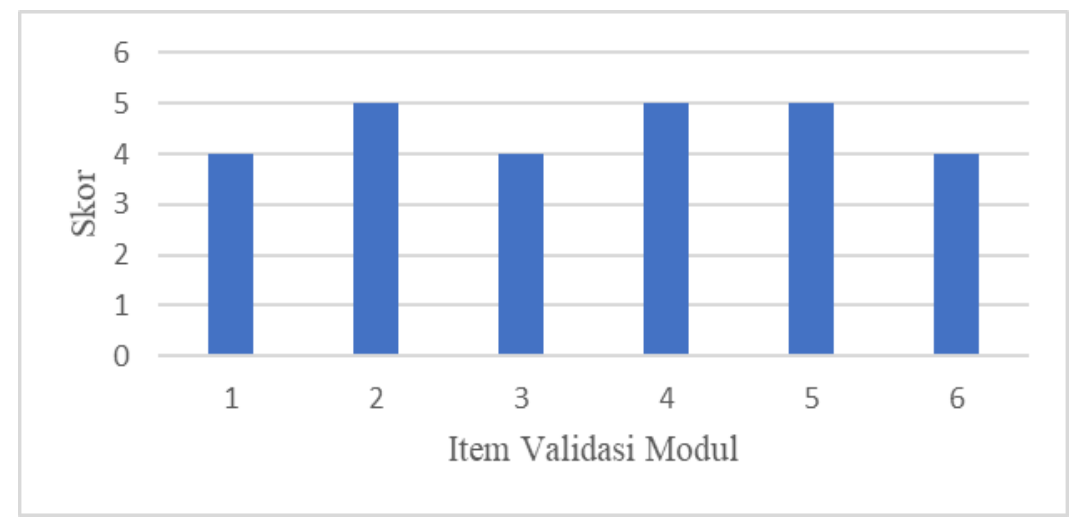

Gambar 2

Hasil Uji Produk di Lapangan

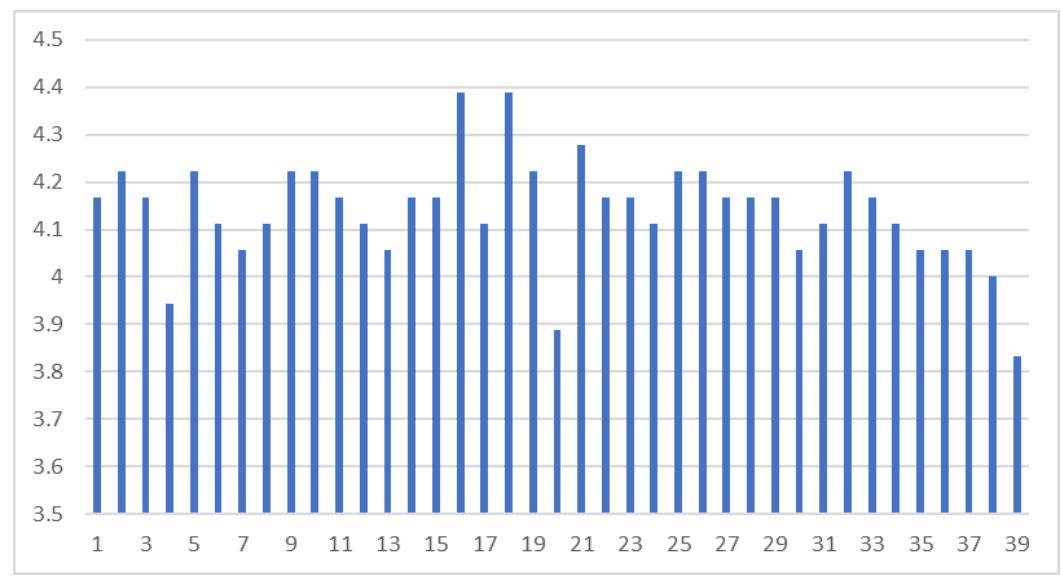

Rumus persentase 1

Prosentase $=\Sigma($ Jawaban $\times$ Bobot tiap pilihan $) \times 100 \%$

$\mathrm{n} \times$ Bobot tertinggi

$$
\text { Persentase }=\frac{(27 \times 1)}{6 \times 100 \%}=\frac{27}{30} \times 100 \%=90 \%
$$

Rumus persentase 2

Prosentase $=\sum$ (Jawaban $\times$ Bobot tiap pilihan $) \times 100 \%$ $\mathrm{n} \times$ Bobot tertinggi

$$
\text { Persentase }=\frac{2808 \times 1}{18 \times(39) \times 5} \times 100 \%=80,00 \%
$$


Tabel 1

Ikhtisar Data Penilaian dan Review Ahli Desain Pembelajaran

\begin{tabular}{cl}
\hline No & Saran/ Komentar \\
\hline 1. & $\begin{array}{l}\text { Layout dan warna cover ditata ulang agar menarik bagi } \\
\text { pembacanya }\end{array}$
\end{tabular}

Tabel 2

Paired Sampel t-test Sikap

\begin{tabular}{|l|l|r|r|r|r|}
\hline \multicolumn{7}{|c|}{ Paired Samples Statistics } \\
\hline \multirow{2}{*}{ Pair 1 } & Mean & $N$ & Std. Deviation & Std. Error Mean \\
\cline { 2 - 6 } & pre test & 64.9744 & 39 & 4.60256 & .73700 \\
\cline { 2 - 6 } & post test & 67.2051 & 39 & 2.82078 & .45169 \\
\hline
\end{tabular}

\begin{tabular}{|l|l|r|r|r|}
\hline \multicolumn{7}{|c|}{ Paired Samples Correlations } \\
\hline & & $N$ & \multicolumn{1}{c|}{ Correlation } & \multicolumn{1}{c|}{ Sig. } \\
\hline Pair 1 & pre test \& post test & 39 & .633 & .000 \\
\hline
\end{tabular}

\begin{tabular}{|c|c|c|c|c|c|c|c|c|c|}
\hline \multicolumn{10}{|c|}{ Paired Samples Test } \\
\hline \multicolumn{7}{|c|}{ Paired Differences } & \multirow{3}{*}{$t$} & \multirow{3}{*}{$d f$} & \multirow{3}{*}{$\begin{array}{l}\text { Sig. }(2- \\
\text { tailed) }\end{array}$} \\
\hline & & \multirow[t]{2}{*}{ Mean } & \multirow[t]{2}{*}{ Std. Deviation } & \multirow{2}{*}{$\begin{array}{l}\text { Std. Error } \\
\text { Mean }\end{array}$} & \multicolumn{2}{|c|}{$\begin{array}{l}\text { 95\% Confidence Interval of the } \\
\text { Difference }\end{array}$} & & & \\
\hline & & & & & Lower & Upper & & & \\
\hline Pair 1 & $\begin{array}{l}\text { pre test-post } \\
\text { test }\end{array}$ & -2.23077 & 3.56490 & .57084 & -3.38638 & -1.07516 & -3.908 & 38 & .000 \\
\hline
\end{tabular}

Tabel 2

Paired Sampel t-test Keterampilan

\begin{tabular}{|l|l|r|r|r|r|}
\hline \multicolumn{7}{|c|}{ Paired Samples Statistics } \\
\hline \multirow{2}{*}{ Pair 1 } & Mean & $N$ & Std. Deviation & Std. Error Mean \\
\cline { 2 - 6 } & pre test & 15.4615 & 39 & 1.55337 & .24874 \\
\cline { 2 - 6 } & post test & 17.2051 & 39 & .92280 & .14777 \\
\hline
\end{tabular}

\begin{tabular}{|l|l|r|r|r|}
\hline \multicolumn{7}{|c|}{ Paired Samples Correlations } \\
\hline \multicolumn{2}{|c|}{ N } & N & Correlation & \multicolumn{1}{c|}{ Sig. } \\
\hline Pair 1 & pre test \& post test & 39 & .501 & .001 \\
\hline
\end{tabular}

\begin{tabular}{|c|c|c|c|c|c|c|c|c|c|}
\hline \multicolumn{10}{|c|}{ Paired Samples Test } \\
\hline & & \multirow[b]{2}{*}{ Mean } & \multirow[b]{2}{*}{ Std. Deviation } & \multirow{2}{*}{$\begin{array}{l}\text { Std. Error } \\
\text { Mean }\end{array}$} & \multicolumn{2}{|c|}{$\begin{array}{l}\text { 95\% Confidence Interval of the } \\
\text { Difference }\end{array}$} & \multirow[b]{2}{*}{$\mathrm{t}$} & \multirow[b]{2}{*}{$d f$} & \multirow{2}{*}{$\begin{array}{l}\text { Sig. }(2 \\
\text { tailed })\end{array}$} \\
\hline & & & & & Lower & Upper & & & \\
\hline
\end{tabular}


Galih Puji Mulyoto. Pengembangan modul praktikum mata kuliah Pancasila menggunakan model project citizen sebagai upaya menanamkan nilai-nilai antikorupsi pada mahasiswa

\begin{tabular}{|l|l|r|r|r|}
\hline \multicolumn{5}{|c|}{ Paired Samples Correlations } \\
\hline \multicolumn{2}{|c|}{} & N & Correlation & \multicolumn{1}{c|}{ Sig. } \\
\hline Pair 1 & pre test \& post test & 39 & .501 & .001 \\
\hline
\end{tabular}

\begin{tabular}{|c|c|c|c|c|c|c|c|c|c|}
\hline \multicolumn{10}{|c|}{ Paired Samples Test } \\
\hline \multicolumn{7}{|c|}{ Paired Differences } & \multirow[b]{3}{*}{$\mathrm{t}$} & \multirow[b]{3}{*}{$\mathrm{df}$} & \multirow{3}{*}{$\begin{array}{l}\text { Sig. }(2 \\
\text { tailed })\end{array}$} \\
\hline & & \multirow[b]{2}{*}{ Mean } & \multirow[b]{2}{*}{ Std. Deviation } & \multirow{2}{*}{$\begin{array}{l}\text { Std. Error } \\
\text { Mean }\end{array}$} & \multicolumn{2}{|c|}{$\begin{array}{l}\text { 95\% Confidence Interval of the } \\
\text { Difference }\end{array}$} & & & \\
\hline & & & & & Lower & Upper & & & \\
\hline Pair 1 & $\begin{array}{l}\text { pre test - post } \\
\text { test }\end{array}$ & -1.74359 & 1.35176 & .21646 & -2.18178 & -1.30540 & -8.055 & 38 & .000 \\
\hline
\end{tabular}

